"This is the peer reviewed version of the following article: [Audit quality and properties of analysts' information environment I He, W.; Sidhu, B.; Taylor, S.

Journal of Business Finance and Accounting, 2019, 46 (3-4), pp. $400-419$

], which has been published in final form at [https://doi.org/10.1111/jbfa.12358]

This article may be used for non-commercial purposes in accordance with Wiley Terms and Conditions for Self-Archiving 


\title{
Audit Quality and Properties of Analysts' Information Environment*
}

\author{
Wen He \\ University of Queensland \\ Baljit Sidhu \\ University of Sydney \\ Stephen Taylor \\ University of Technology Sydney
}

August 2018

\footnotetext{
${ }^{*}$ This research was supported by the Australian Research Council and the Accounting and Audit Quality Research Program funded by the Capital Markets Co-Operative Research Centre (Capital Markets CRC Ltd) established by the Federal Government of Australia. We gratefully acknowledge the helpful comments by Andrew Stark (the editor), an anonymous reviewer, Jay Jung (JBFA Conference discussant), Jeff Callen, Neal Fargher, Jere Francis, Jim Ohlson, Katherine Schipper, Joe Weber and Mark Wilson, as well as attendees at the JBFA Capital Markets Conference, the UTS Summer Accounting Symposium, the International Symposium on Audit Research (ISAR), the University of Sydney MEAFA Conference and workshop participants at the following universities: Australian National University, University of South Australia, and University of New South Wales. All data used are publicly available.
} 


\title{
Audit Quality and Properties of Analysts' Information Environment
}

\begin{abstract}
We consider how audit quality impacts sell-side analysts' information environment. Using the method outlined by Barron et al. (1998), we examine whether higher audit quality is associated with differences in the weight analysts place on common information relative to private information, as well as the extent to which audit quality separately impacts the precision of analysts' private and common information. Our results show that, in instances where analysts revise their earnings forecasts for year $t+1$ shortly after the release of year $t$ earnings, higher audit quality results in analysts placing more weight on public information. The precision of private (as well as public) information is improved. These results extend our understanding of how audit quality impacts on attributes of analysts' forecasts and provides support for the argument that audit quality has important capital market implications.
\end{abstract}

Key Words: Audit quality, analysts' earnings forecasts, information environment. 


\section{Introduction}

The aim of this paper is to extend our understanding of how audit quality impacts capital market participants, specifically sell-side analysts. Prior research generally finds that high-quality auditors are associated with improved quality and reliability of accounting information (Dechow et al. 2010; Reichelt and Wang 2010; Francis 2011). There is also extensive evidence that capital market participants seem to differentiate and value audit quality. ${ }^{1}$ One stream of research focuses on financial analysts (e.g., Abernathy et al. 2016, Behn et al. 2008, Wu and Wilson 2016). Examination of how audit quality impacts on sell-side analysts is appealing, because as Bradshaw (2009) notes, analysts are typically assumed to be an important group of relatively informed financial statement users. Hence, it seems reasonable to assume that audited financial statements are a key input into analysts' forecasting process, especially in the setting we examine, namely analysts' forecast revisions immediately following firms' annual earnings announcements. ${ }^{2}$

Behn et al. (2008) show that higher audit quality (measured by Big $\mathrm{N}$ audit firms) is associated with increased accuracy and reduced dispersion in earnings forecasts issued by sell-side analysts. However, some studies explicitly question whether financial analysts actually pay attention to audit quality. For example, Donovan et al. (2014) examine the transcripts of conference calls and find that analysts rarely mention and question the audit or auditors. Further, a recent survey of sell-side analysts (Brown et al. 2015) suggests that analysts rate an audit by a Big 4 auditor as a relatively less important signal of earnings quality. ${ }^{3}$ Additional concerns also arise from the sensitivity of Behn et al.'s results to the way in which auditor quality is captured. In contrast to their results using a simple Big $\mathrm{N}$ distinction, they are unable to identify within the Big $\mathrm{N}$ sample any association between properties of analysts' forecasts and measures of industry specialization, which are commonly accepted as an indicator of audit quality (DeFond and Zhang 2014).

\footnotetext{
${ }^{1}$ Examples include initial public offering valuation (IPOs) (Feltham et al. 1991; Weber and Willenborg 2003), the cost of debt (Pittman and Fortin 2004; Mansi et al. 2004), earnings response coefficients (Teoh and Wong 1993; and earnings (i.e., accrual) valuation (Krishnan 2003). Aobdia et al. (2015) discuss and use several of these measures.

${ }^{2}$ In a similar manner, Bradshaw et al. (2001, p. 46) characterize sell-side analysts as "professional investment intermediaries who specialize in interpreting accounting information".

${ }^{3}$ An important caveat is that Brown et al. (2015) survey analysts who typically follow larger companies, which typically have Big 4 auditors. Hence, these analysts may not see auditor identity as a distinguishing characteristic.
} 
Our research extends prior evidence of an association between audit quality indicators and the actions of sell-side analysts. In contrast to earlier studies that examine the association between indicators of audit quality and properties of analysts' forecasts such as accuracy and dispersion (Behn et al. 2008; Payne 2008; Wu and Wilson 2016), we investigate the extent to which indicators of audit quality are associated with properties of analysts' information environment. Specifically, we investigate whether widely used indicators of audit quality (i.e., Big $\mathrm{N}$ auditor status and auditor clientindustry specialization) are associated with more precise common and/or private information being reflected in revisions of analysts' forecasts for year $t+1$ immediately following the release of earnings for year t. Our evidence therefore speaks to the question of whether analysts place more weight on audited financial statement information when audit quality is expected to be higher.

It is generally believed that analysts' information set contains both public (i.e., common) and idiosyncratic (i.e., private) components (Chen and Jiang 2006). The common information set available to all analysts includes the contents of audited financial statements, and it is well documented that analysts use financial statement information to formulate and revise earnings forecasts (e.g., Abarbanell and Bushee 1997; Schipper 1991; Zhang 2008; Barron et al. 2017, Bradshaw et al. 2018). There is extensive evidence that commonly used proxies for audit quality such as audit firm size and client industry specialization are associated with higher quality financial reports (Reichelt and Wang 2010; Dechow et al. 2010; Kanagaretnam et al. 2010; Jin et al. 2011; DeBoskey and Jiang 2012). Provided these attributes impact actual inputs to analysts' decision processes, we expect they will assign more weight to the financial statements audited by a high-quality auditor. Therefore, we expect a positive association between audit quality and the weight on common information reflected in analysts' earnings forecasts.

Furthermore, if high quality audits help to improve the quality of financial statements and make publicly available accounting information more informative of future earnings, then we expect a positive association between audit quality and the precision of analysts' common information. As we have already noted, audit quality is associated with several attributes of financial reporting that are likely to result in less 
manipulated financial statements. For example, higher audit quality has been shown to be associated with lower absolute unexpected accruals (Becker et al. 1998). Unexpected accruals are also far less predictive of future earnings than either the cash or expected accrual components (Xie 2001). As audited financial statements are generally available to all analysts, then to the extent analysts rely on common information they should all benefit from higher audit quality.

Finally, audit quality could also affect the precision of analysts' private information, although the direction of any predicted effect is unclear. On the one hand, public and private information may be substitutes (Verrecchia 1982; Kim and Verrecchia 1991). In this case, improved quality of public information resulting from higher audit quality may reduce analysts' incentive to acquire private information. On the other hand, if a subset of analysts has superior information processing skills, then higher quality common information may allow certain analysts to develop idiosyncratic insights that are not commonly shared (Kim and Verrecchia 1994, 1997), resulting in an improvement in the precision of analysts' private information. Although Byard and Shaw (2003) find that higher corporate disclosure quality is associated with increased precision in both the common and private information of analysts, the expected effect for audit quality is ultimately dependent on the means by which audit quality and private signals interact. While this is ultimately an empirical question, we expect that any change in the precision of analysts' private information will be less than the increase in the precision of common information, thereby resulting in an overall increase in the weight on common information.

Our empirical measures of the relative weights analysts place on common and private information, as well as their respective precisions, are taken from Barron et al. (1998, hereafter BKLS). While these measures have been used to examine analysts' information environment in a number of settings (Barron et al. 1998, 2002, 2005, 2008; Byard and Shaw 2003; Botosan and Plumlee 2004; Mohanram and Sunder 2006; Byard et al. 2011; Han et al. 2013; Altschuler et al. 2015; Barron et al. 2017; Bradshaw et al. 2018; Keshk and Wang 2018), we are unaware of any examples where their association with commonly used indicators of audit quality has been considered. Consistent with the approach suggested in Barron et al. (2017) and Bradshaw et al (2018), we use analysts' earnings forecast revisions following the 
release of annual earnings results to derive measures of the change in consensus (i.e., the change in the proportion of total information represented by common information), and changes in the precision of analysts' common and private information. Applying this approach enables us to show how audit quality impacts on underlying characteristics of analysts' information set via reactions to the release of audited earnings (in this case, consensus and precision) rather than just examining the correlation with forecast attributes such as accuracy and dispersion.

Using a Big $\mathrm{N}$ indicator and multiple measures of auditor industry specialization as a proxy for higher audit quality, the results consistently show that higher quality audits are associated with a larger increase in analysts' consensus, supporting our prediction that analysts incorporate more common information into their forecasts for firms using higher quality auditors. Further, we find that the precision of both analysts' common and private information tends to increase more when a firm's financial statements are audited by a high quality auditor. The results are also robust to several forms of sensitivity analysis, including attempts to control for endogenous auditor choice as well as an alternative method for estimating the precision of analysts' private and public information.

Our study makes two important contributions. First, we add to the literature that examines how audit quality affects decision making by users of financial statements and, by implication, the role of audit quality in capital markets. Other than documenting an association between audit quality indicators and forecast attributes such as accuracy and dispersion (Behn et al. 2008), there is relatively little evidence explicitly linking audit quality to attributes of information underlying sell-side analysts' forecasts. An exception is Cahan et al. (2013) who provide evidence that analysts' forecasts are influenced by their perceptions of audit quality. However, their focus is specifically on the collapse of Arthur Andersen and its effect on forecasted earnings of their clients. ${ }^{4,5}$ Our results utilize quite different dependent variables from prior research, showing that audit quality has a significant impact on the information

\footnotetext{
${ }^{4}$ Another example is Abernethy et al. (2016), who examine the relation between unexpected audit fees and analysts' forecasts. However, the manner in which unexpected audit fees reflects high versus low audit quality is unclear (DeFond and Zhang 2014).

${ }^{5}$ In a similar manner to Cahan et al. (2013), Autore et al. (2009) examine capital market effects of the announcement by Arthur Andersen of document shredding. However, they focus on stock price reactions, rather than direct effects on sell-side analysts' output.
} 
environment of financial analysts, namely the relative weights analysts place on private versus common information. We therefore provide a richer picture of how audit quality impacts sell-side analysts, who are widely recognized as relatively sophisticated users of audited financial statements. In doing so, we also contribute to research on analysts' information processing by showing that analysts rationally use more common information and develop more precise private information when audit quality is higher. Our results also support the argument of DeFond and Zhang (2014), who argue that analysts are likely to have an interest in audit quality variation.

Second, we utilize a different experimental design than prior studies to show that higher quality audits (as captured by client-firm industry specialization) are positively associated with the precision of analysts' common and private information. Studies which focus solely on attributes of analysts' short term earnings forecasts such as accuracy or dispersion (Behn et al. 2008; Payne 2008) may potentially confuse the role of accounting information (and by implication, audit quality) with numerous other information sources such as management earnings forecasts and the myriad other data sources observed by analysts over the financial year that are correlated with future earnings outcomes (Wu and Wilson 2016). ${ }^{6}$ However, simply substituting longer range forecasts is unlikely to provide a solution, as these forecasts are still not explicitly linked to information events where the quality of accounting information is likely to be a focus. In contrast, our method explicitly focuses on measures that reflect analysts' reaction to the release of audited financial results. It is well known that analysts frequently revise their recommendations shortly after an earnings release (Yezegel 2015), consistent with the effect of accounting (and audit) quality being most relevant at the time point when analysts likely place most weight on accounting information. Our use of changes in the BKLS measures associated with analysts' forecast revisions surrounding the release of audited annual earnings figures is more likely to explicitly reflect the information effect of audit quality on sell-side analysts than prior research (Bradshaw et al. 2018). It also has the advantage of reducing endogeneity concerns in interpreting the results.

The remainder of the paper proceeds as follows. Section 2 briefly outlines the method

\footnotetext{
${ }^{6}$ In addition, Lawrence et al. (2011) argue that the results reported by Behn et al. (2008) linking Big N auditors with increased forecast accuracy are largely a result of the failure to adequately control for client-firm differences between Big $\mathrm{N}$ and non-Big $\mathrm{N}$ clients.
} 
suggested by BKLS for measuring the quality of common and idiosyncratic information available to analysts, as well as our hypotheses. In section 3 we describe our measures of audit quality, the sample selection and the method used to empirically estimate the measures suggested by BKLS (i.e., forecast revisions immediately after earnings releases). Section 4 reports our results, as well as several sensitivity tests and robustness analysis. Section 5 concludes.

\section{Background and hypotheses}

\subsection{Measuring analysts' information environment}

BKLS develop a model of analysts' forecasting process in which $\mathrm{N}$ analysts following a firm possess two signals about future earnings. One signal is public (i.e., it is common across all analysts) and the other is private (i.e., it is idiosyncratic). The common information is identical across all the analysts, while the private information is unique and is independently normally distributed with mean zero. Common information has precision $h$ and private information has precision $s$. When formulating forecasts, analysts weight their common and private information by their respective precision ( $h$ or $s$ ).

BKLS define consensus $(\rho)$ as the degree to which individual analysts' forecasts contain the same information. In other words, consensus is the ratio of common to total information in an analyst's forecast. This is also consistent with the consensus concept outlined by Holthausen and Verrecchia (1990). The BKLS consensus measure enables inferences to be drawn about the extent to which analysts base their forecasts on public information relative to private information. Intuitively, the approach suggested by BKLS reflects the assumption that the dispersion of earnings forecasts among analysts reflects the extent to which there is idiosyncratic information among analysts, and the information which is common among all analysts is measured by the squared error of the mean analysts' forecast.

Most importantly, BKLS show that their consensus measure can be directly inferred from the observable forecast dispersion, error in the mean forecast, and the number of forecasts. Hence, consensus can be expressed as follows: 


$$
\rho=\frac{(S E-D / N)}{(S E-D / N+D)}
$$

where $S E$ is the expected squared error in the mean forecast, $D$ is the expected forecast dispersion, and $N$ is the number of analysts. ${ }^{7}$

Under certain assumptions, BKLS also show that $\rho$ can be interpreted as the average proportion of total information represented by common information in all analysts' forecasts (i.e., the degree of commonality in the average forecast). First, analysts' forecasts must be unbiased, on average. Biased forecasts would inflate the common error, resulting in an overstatement of the extent to which forecasts reflect common, as distinct from private information. However, our sample selection process (outlined below) addresses this issue to some extent by focusing exclusively on forecast revisions immediately after earnings releases.

The second important assumption made by BKLS is that actual earnings results do not reflect systematic earnings management aimed at meeting or beating the forecast (i.e., "benchmark beating"). We think this is a reasonable assumption for two reasons. First, prior evidence has failed to establish a link between apparent evidence of benchmark beating and firm-specific measures of earnings management such as unexpected accruals (Dechow et al. 2003). Second, there are serious doubts about whether apparent discontinuities around benchmarks such as analyst' forecasts can even be interpreted as evidence of benchmark beating via earnings management (Durtschi and Easton 2005, 2009).

BKLS further extend their analysis by invoking an assumption that analysts' idiosyncratic information is equally precise. ${ }^{8}$ Under the assumption of such homogenous precision, BKLS show that the precision of common information $(h)$ and private information $(s)$ can also be expressed directly in term of $S E, D$ and $N$, in the

\footnotetext{
7 The obvious inference is that as the number of analysts following a firm, N, becomes large, idiosyncratic errors in the mean forecast tend to cancel out.

${ }^{8}$ The assumption that analysts have equally precise private information is appropriate if analysts are all relatively well informed, with little difference in the quality of information available to them. Extant research generally fails to find consistent differences in forecast error magnitude across analysts, which supports this assumption (Beyer et al. 2010). We also consider an alternative estimation method which relaxes the assumption of equally precise private information ( $\mathrm{Gu} 2004)$ and find similar results (see section 4).
} 
following equations:

$$
\begin{aligned}
& h=\frac{(S E-D / N)}{(S E-D / N+D)^{2}} \\
& s=\frac{D}{(S E-D / N+D)^{2}}
\end{aligned}
$$

As BKLS note, their measures reflect unconditional expectations of forecast dispersion and error in the mean forecast $(D$ and $S E$ ). Empirical implementation of this approach requires pooling of observations to measure dispersion and error in the mean forecast. However, averaging of multiple observations has the advantage of reducing measurement error and therefore enhanced construct validity. Following prior studies (Barron et al. 2002; Byard and Shaw 2003; Bradshaw et al. 2016; Barron et al. 2017), we focus on analysts forecast revisions following earnings releases as our source of data for these variables.

\subsection{Hypotheses}

As we have noted, Behn et al. (2008) demonstrate that higher audit quality is associated with less dispersed and more accurate forecasts of earnings by sell-side analysts. If audit quality influences analysts' reliance on audited financial data, then we would expect to see a higher proportion of common information reflected in the mean forecast, as audited financial statements are public information readily available to all analysts. This would result in increased consensus as defined by BKLS (i.e., greater relative weight on common information). In the context of audit quality, we expect that financial statement data used as inputs to earnings forecasts will be more precise when it is audited by a high quality auditor. Hence, our first two hypotheses can be stated in alternative form as:

H1: Higher audit quality is associated with increased consensus in analysts' earnings forecasts

H2: Higher audit quality is associated with increased precision of the common information component in analysts' earnings forecasts 
We acknowledge that the impact of higher audit quality on the private component of analysts' information is dependent, at least in part, on the extent to which private and common information act as substitutes or complements. While theoretical arguments can be advanced to support either scenario, prior evidence that disclosure quality is related to the precision of analysts' private information (Byard and Shaw 2003) leads us to expect that audit quality may also be associated with an improvement in the precision of analysts' private information, but not to the same extent as occurs with common information. In other words, intuitively we expect the incremental impact of publicly observable audit quality on private information precision is less than the effect on public information precision, thereby resulting in an increase in consensus. Our third hypothesis can be stated in alternative form as:

H3: Higher audit quality is associated with increased precision in the private information component in analysts' earnings forecasts.

\section{Research method and sample selection}

\subsection{Measuring audit quality}

Following prior studies, we identify instances of higher audit quality based on measures of BigN auditor status and auditor client-industry specialization. Big $\mathrm{N}$ auditors have been shown to be related to higher audit quality due to their incentives and competence (Watts and Zimmerman, 1981; DeFond et al., 2017). Industry specialist auditors are more likely to provide higher quality audits, since they are better able to detect errors within their industry specialization than other accounting firms (Craswell et al. 1995) As with auditor size, there is considerable evidence of industry specialist auditors receiving economically significant fee premiums (Francis et al. 2005), as well as being associated with higher quality financial reporting (Balsam et al. 2003; Krishnan 2003; Reichelt and Wang 2010; Kanagaretnam et al. 2010; Jin et al. 2011; DeBoskey and Jiang 2012).

Following Balsam et al. (2003) we use four proxies for auditor industry specialization. The first two proxies are measures of the auditor's market share in an industry defined by two-digit SIC code, where market shares are computed based on client sales and the number of clients respectively. The next two proxies are dummy variables indicating the auditor with the largest market share in each two-digit SIC 
code industry (i.e., "market leader"), and again market shares are calculated in terms of client sales and the number of clients respectively. All of our tests rely on audit markets at the national level and reflect client-based measures of industry specialization and leadership, rather than being restricted to the audit firm client portfolio (i.e., a specialist (or leader) is based on the relevant client-firm industry, and not restricted to how a given audit firm's portfolio of clients is comprised). This approach is consistent with the evidence provided by Audousset-Coulier et al. (2016), who provide an extensive set of validation tests for a wide variety of measures used to capture audit firm specialization. They conclude (pg. 153) that measures based on large market shares at the client-industry level are "the most consistent and valid ones for measuring audit quality". 9

\subsection{Sample selection}

Our main analyses are based on a sample of U.S firms. We rely on the IBES unadjusted detail database to obtain individual analysts' forecasts of annual earnings for year $\mathrm{t}+1$ from 1985 to 2015 (Payne and Thomas 2003). Our sample selection procedure closely follows Byard and Shaw (2003). Specifically, we select forecasts issued during the 30-day period immediately after the announcement of earnings of year $t$. We further require that these forecasts are the updates of previous forecasts made during the 60-day window immediately before the earnings announcement. Barron et al. (2002) identify several reasons for using this approach. First, analysts who update their forecasts immediately after the earnings announcement are more likely to use their own information and less likely to "herd". Herding among analysts may cause under-estimation of forecast dispersion and introduce measurement error. Second, these forecast revisions are conditioned on the same set of information, namely annual earnings announcements. This is particularly relevant to our study since we are interested in how audit quality, through annual financial statements, affects analysts' information environment. Third, this selection procedure controls for forecast recency and excludes stale forecasts that would likely inflate forecast dispersion. Once Compustat data requirements are met, we have a sample of 25,111 firm-years (5,353 unique firms). Table 1 summarizes our step-by-step sample selection process.

\footnotetext{
${ }^{9}$ We briefly consider possible alternative indicators of audit quality in our sensitivity analysis.
} 


\subsection{Research method}

We use analysts' forecasts issued immediately after the annual earnings announcement to calculate realized forecast dispersion $(\hat{D})$ and squared error in the mean forecast $(S \hat{E})$ as follows:

$$
\begin{aligned}
& \hat{D}=\frac{1}{N-1} \sum_{i=1}^{N}\left(F_{i}-\bar{F}\right)^{2} \\
& S \hat{E}=(A-\bar{F})^{2}
\end{aligned}
$$

where $F_{i}$ is forecast issued by an individual analyst $i, \bar{F}$ is the mean analyst forecast, $A$ is the actual annual earnings (as stated by IBES), and $N$ is the number of analysts.

We scale both realized dispersion $(\hat{D})$ and squared error in the mean forecast $(S \hat{E})$ by the absolute value of actual annual earnings. To eliminate extreme values caused by the scaling variable, we delete observations with an absolute value of actual earnings of less than 10 cents per share. We then substitute $\hat{D}, S \hat{E}$ and $N$ into equations 1,2 and 3 to obtain the estimated analyst consensus, as well as the precision of analysts' common and private information.

To calculate meaningful forecast dispersions, we require that at least two analysts update their annual earnings forecasts for year $t+1$ within the 30 -day period following the announcement of earnings of year t. Given that the BKLS model requires the precision of information ( $h$ and $s$ ) to be non-negative, we exclude estimates where $h$ is negative (by definition, $s$ cannot be negative). To test our hypotheses, we estimate the following ordinary least square regressions, using changes in $\rho, h$ and $s$ as the dependent variable $(D V)$ :

$$
\mathrm{DV}=\alpha+\beta_{1} \text { Audit }+\beta_{2} \text { Surp }+\beta_{3} \text { Size }+\beta_{4} \mathrm{MB}+\beta_{5} \text { Analysts }+\varepsilon
$$

Following Bradshaw et al. (2018) and Barron et al. (2017), we use changes in the BKLS measures as the dependent variables. Using changes of the measures also helps 
address endogeneity concerns. Unlike the levels of these measures that are likely to be correlated with audit quality due to firms' financial reporting choices, ${ }^{10}$ changes in BKLS measures more likely reflect changes in analysts' information environment surrounding the annual earnings announcements.

Audit is our measure of audit quality at the end of year t. The hypothesis that higher audit quality results in larger improvements to analysts' information environment predicts $\beta_{1}>0$, namely increased consensus and greater precision of public (and possibly) private information for clients of high quality auditors.

We include controls for previously identified determinants of the properties of analysts' information environment (Barron et al. 2008; Barron et al. 2017). Barron et al. (2008) find that large earnings surprises are followed by a decrease in analyst consensus but an increase in the precision of analysts' private information. This suggests that large earnings surprises motivate analysts to increase their private information search efforts, which in turn lead to their earnings forecasts reflecting a higher precision of private information. We measure earnings surprises by Surp, computed as the absolute value of the difference between the actual and mean forecasted earnings per share for year $t$, deflated by the absolute value of actual earnings per share of year t. Size is a common proxy for the level of a firm's information available to investors. Lys and Soo (1995) show that firm size is positively related to analysts' information precision. We measure firm size as market capitalization (in millions of dollars) at the end of year $\mathrm{t}$. We also include the marketto-book ratio $(M B)$ at the end of year $t$, to control for firm characteristics related to growth opportunities. Finally, we include the number of analysts (Analysts) at the end of year t, since Barron et al. (2008) show that more analysts updating their forecasts will incorporate more private information into the forecasts and thus reduce the consensus.

Our dataset is an unbalanced panel consisting of repeated observations from the same set of firms over time. One issue with panel data is that variables often demonstrate both cross-sectional and serial correlation, which could result in mis-specified test

\footnotetext{
${ }^{10}$ In unreported results, we find that the levels of BKLS measures are all positively related to the measures of audit quality.
} 
statistics. To avoid this problem, we adjust standard errors for clustering effects at both firm and year level (Petersen 2009; Gow et al. 2010).

\section{Results}

\subsection{Descriptive statistics}

Our final sample consists of 25,111 firm-year observations with non-missing values for calculating our measures of the properties of analysts' information environment, and for all of our explanatory variables. Table 2 presents descriptive statistics for the sample. On average, $94.3 \%$ of sample firms are audited by a BigN auditor, and about a quarter of sample firms are audited by an industry specialist auditor that has the largest market share in the relevant industry. ${ }^{11}$ The sample firms tend to have relatively large market capitalizations. This is not surprising given we require sample firms to be followed by at least two financial analysts and this is more likely to capture large firms. The mean value for the change in consensus, $\Delta \rho$, is positive, as is the change in precision of both analysts' common information, $\Delta h$, and private information, $\Delta s .^{12}$

Our estimates of the change in analysts' information precision are highly skewed, as are some of the explanatory variables. It is also possible that there is a non-linear relation between our measures of changes in the properties of analysts' information and the explanatory variables. Thus, following prior research (Barron et al. 2002, Byard and Shaw 2003), we use rank regressions to perform multivariate analysis. ${ }^{13}$ Finally, since we define auditor industry specialization based on auditors' industry market share in a year, we rank all of our variables within each industry in the year, where an industry is defined by its two-digit SIC code.

\section{Insert Table 2 here}

\footnotetext{
${ }^{11}$ Given that analysts tend to cover larger firms, the high rate of Big $\mathrm{N}$ usage is not surprising.

${ }^{12}$ Some prior studies examining the change in consensus around earnings releases report that the average change is negative (Barron et al. 2002; Barron et al. 2008; Barron et al. 2017). However, closer investigation shows that our requirement that $h$ must be positive (see section 3.3) explains this difference. If observations where $\mathrm{h}$ is negative are included, we find a negative mean value for $\Delta \rho$.

${ }^{13}$ The ranking of the continuous variables by industry and year is equivalent to the estimation of industry and year fixed effects. Hence, we do not include such fixed effects separately in our regression estimates. In un-tabulated analysis, we confirm that ranking without reference to industry and year, but with additional inclusion of industry and year fixed effects yields similar results to those discussed in section 4.
} 
Since we use ranked regression in the multivariate analysis, we report the correlation coefficients of ranked variables in Table 3. Consistent with the BKLS model, we find that the change in consensus in analysts' forecasts, $\Delta \rho$, is positively related to the changes in the precision of analysts' common information $\Delta h$. Interestingly, $\Delta h$ and $\Delta s$ are also positively related, suggesting that analysts' common and private information may be complementary to each other. More importantly, $\Delta \rho, \Delta h$, and $\Delta s$ are positively related to all five measures of audit quality. This lends some support to our hypotheses that higher audit quality is positively associated with both increased common information in analysts' forecasts, and higher precision of analysts' information.

Unsurprisingly, the five measures of audit quality are also positively associated with each other. Furthermore, $\Delta \rho, \Delta h, \Delta s$ are positively related to firm size, market-to-book ratio and the number of analysts following.

Insert Table 3 here

\subsection{Regression results}

In Table 4 we report results from ranked regressions using changes in $\rho, h$ and $s$ as dependent variables. Panel A shows models where the dependent variable $(\Delta \rho)$ represents the change in the consensus $(\rho)$ in analysts' forecasts from before to after the annual earnings announcement. We find that measures of audit quality are positively associated with changes in analyst consensus, suggesting that analysts give more weight to public information when forecasting earnings for firms with higher audit quality. These results are consistent with the results reported by Behn et al. (2008), that analysts' forecasts become less dispersed when audit quality is higher. BKLS show that analysts' forecast dispersion is smaller when the consensus among analysts is higher, or when the uncertainty about the firm's future is lower. Our evidence of increased consensus supports the argument that the smaller forecast dispersion reported by Behn et al. is most likely a reflection of increased use of common information as a result of higher audit quality.

Panel B of Table 4 presents the results from regressions using changes in the precision of analysts' common information $(\Delta h)$ as the dependent variable. The coefficients of 
measures of audit quality are all positive and statistically significant. Taken together, the results in Panels A and B strongly support the prediction that higher quality audit is positively associated with more accurate common information that analysts use to develop their earnings forecasts.

In our final set of tests (Table 4 Panel $\mathrm{C}$ ), we examine the association between audit quality and the change in the precision of analysts' private information $(\Delta s)$. As we have noted, the expected effect of audit quality on the precision of analysts' private information is less clear, reflecting uncertainty about the relation between private and common information. However, consistent with the univariate evidence in Table 3, analysts' private information precision is positively associated with all the five measures of audit quality. These results suggest that higher quality audits also help analysts improve the precision of their private information. This is also consistent with Byard and Shaw (2003), who report that the precision of analysts' private information is increasing in the quality of public disclosures. A further inference is that analysts develop private information partly from processing public information.

\section{Insert Table 4 here}

\subsection{Sensitivity analysis}

The auditing literature has advanced several possible indicators for differential audit quality in addition to the ones that we report in the main results in Tables 4 and 5 (DeFond and Zhang 2014). These alternative measures include audit fees and total fees, auditor tenure, and audit reporting lags. However, these measures typically reflect interaction between the client and the auditor, in contrast to our focus above on measures that reflect the structure of the market for audit services. Nevertheless, there is empirical evidence that higher audit fees, longer auditor (partner) tenure, and shorter audit reporting lags are associated with outcomes consistent with higher audit quality, such as the probability of restatement (e.g., Blankley et al., 2012, 2014; Carey and Simnett, 2006; Geiger and Raghunandan, 2002). Hence, in sensitivity tests, we use each of these alternative measures of audit quality to re-estimate equation (6). ${ }^{14}$

\footnotetext{
${ }^{14}$ For brevity, all of the sensitivity results we discuss are not tabulated. Full results are available from the authors.
} 
The un-tabulated results show that audit fees and total fees are positively related to changes in $\rho, h$ and $s$, suggesting that higher fees are likely to be related to higher audit quality and thus better information environment for financial analysts. Furthermore, auditor tenure is positively associated with BKLS measures of analysts' information environment, implying that longer audit tenure is conducive to higher audit quality and improved information for analysts. Surprisingly, we find a positive relation between audit reporting lags and changes in $\rho, h$ and $s$, implying a longer reporting lag is positively associated with an increase in common information in analysts' forecasts after controlling for earnings news and firm characteristics.

We conduct additional tests to further establish the robustness of our results. These tests address possible concerns about our sample selection process, the measurement of precision, the appropriate level of industry grouping, the identification of industry specialist auditors and the possible interaction between audit quality and the extent of earnings surprises. We briefly discuss each of these tests in turn.

Our sample selection requires that analysts update their pre-announcement forecasts within 30 days of the annual earnings announcements. In additional tests, we relax the requirement of a pre-announcement forecast, and use all the earnings forecasts issued in the 30-day window following the earnings announcement. Our results remain unchanged with this larger sample.

The method for estimation of the precision of analysts' common information $(h)$ and private information $(s)$ is based on the assumption that analysts' private information is equally precise. $\mathrm{Gu}$ (2004) relaxes this assumption and develops a model to estimate $h$ and $s$ without assuming that $s$ is equal across analysts, where the average precision of analysts' private information can be estimated using observed analyst forecasts. We follow this approach and re-estimate $h$ and $s$. Our results remain unchanged.

We also consider the sensitivity of our results to our definition of client-industry used to identify specialist auditors. In the results reported in Table 4, we estimated ranked regressions having ranked the variables within industry, where industries are defined at the two-digit SIC code. For robustness we also identify industries based on onedigit SIC codes or the Fama-French 48 industry classification. We find similar results 
using these two different industry classifications.

Finally, we examine whether our results are robust to including an interaction term between our audit quality proxies and the magnitude of the earnings surprise. In our tests reported in Table 4, we assume audit quality is independent of forecast error, but it is possible that audit quality is directly associated with forecasting behavior (Ball et al. 2012) and therefore captures aspects of disclosure other than the quality of earnings releases. However, all of our primary results remain unchanged after including this interaction term.

\subsection{Endogenous auditor quality}

A possible alternative explanation for an association between analysts' information environment and audit quality is the endogenous selection of higher quality auditors (i.e., the possibility that client industry market share is associated with characteristics that also explain, at least in part, differences in analysts' precision). As an example, consider client firm size. Recall that the BKLS consensus and precision measures are computed from unconditional estimates of the dispersion and error in mean forecasts (see section 2.1). Given that these are correlated with firm size, it is not surprising that the resulting BKLS measures of consensus and precision are also correlated positively with firm size. We also expect that firm size is associated with the demand for audit quality, and to some extent there is a mechanical relationship between client marketshare based measures of audit quality and client firm size (Minuti-Meza 2013). ${ }^{15}$

However, we utilize a research design which focuses on changes in analysts' information environment, rather than levels per se. Changes in the BKLS measures reflect the level of these measures prior to the earnings release, and the change induced by this announcement. While the pre-announcement level of these variables is potentially impacted by endogeneity, changes associated with the earnings release

\footnotetext{
${ }^{15}$ Minutti-Meza (2013) uses three proxies for the accounting effects of higher audit quality (i.e., proxies for higher accounting quality). These are the absolute value of unexpected accruals, meeting or beating analysts' forecasts, and the propensity to issue a going concern audit opinion. Only the tests using unexpected accruals yield initial evidence of potentially spurious auditor specialization effects, and we note that these are tests of absolute (rather than signed) unexpected accruals. More generally, each of these proxies has been shown to lack power and/or be subject to significant biases in detecting earnings management, even when there is a clear incentive to engage in such behaviour (Dechow et al. 2010). It is therefore unclear to what extent these problems offer an alternative explanation for the results.
} 
are not, and so at least in part serve to "control" for endogenous auditor selection. ${ }^{16}$

Nevertheless, we also endeavor to address endogeneity concerns in several ways. ${ }^{17}$ First, we use a two-stage Heckman (1979) procedure, where our first stage regression estimates the likelihood of selecting a Big $\mathrm{N}$ auditor or a client industry specialist/leader auditor, while the second stage includes the inverse Mills ratio (IMR) as an additional term in the regressions reported in Table 4. Our first stage regression models the selection of a higher quality auditor as a function of firm size, asset mix (property plant and equipment as a percentage of total assets, the sum of receivables and inventory as a percentage of total assets), leverage, profitability (an indicator for a reported loss and a measure of ROA) and the issuance of debt during the reporting period. Of these variables, only firm size is controlled for in the second stage - the other variables are assumed to be at least largely exogenous of the analyst forecast properties that we model (Lennox et al. 2012). When we include the estimated IMR as an additional variable we find that it is significant, but our inferences about the audit quality proxies do not change from those reported in Table 4.

However, as noted by Lennox et al. (2012), conclusions about the existence and direction of selection bias (and therefore, the extent to which results are robust to such biases) are entirely dependent on our choice of exclusion restrictions. One possible alternative is the use of propensity scores to create a "matched" sample, in the manner suggested by Lawrence et al. (2011) and Minutti-Meza (2013). Propensity score matching (PSM) assumes selection occurs only on the variables used to identify the matched sample, and is premised on the assumption that an appropriate comparison is between (in this case) firms using an auditor identified as high quality and those which, in some respects "should" make such a choice but do not. More worryingly, DeFond et al. (2014) show that the results in Lawrence et al. (2011) are very sensitive to research design choices, and suggest an alternative, namely coarsened exact matching (CEM).

At a general level, both PSM and CEM require matching on some firm characteristics, but we observe relatively little consensus on what those characteristics should be. We

\footnotetext{
${ }^{16} \mathrm{We}$ are grateful to the reviewer for suggesting this point.

${ }^{17}$ Full details are available from the authors.
} 
follow Minutti-Meza (2013) and choose two sets of characteristics for matching. The first set contains only firm size, and year and industry fixed effects. The second set includes firm size, property, plant and equipment, the sum of receivables and inventories, leverage, a loss dummy, return on assets and a dummy variable capturing debt issuance, as well as year and industry fixed effects. For PSM, we first estimate a probit model of auditor choice using firm characteristics, and obtain the propensity score which is basically the estimated probability of hiring an industry specialist auditor. Then we find matched firms with the closest propensity scores. In CEM, firm characteristics are first grouped into "bins" based on the range of characteristics. Then firms are matched to those in the same bin. A choice for CEM is the number of such bins, and we use the STATA package and the autocuts option to select the number of bins.

After matching, we repeated the analysis in Table 4. It is apparent that the PSM results are sensitive to the choice of treatment-to-control ratio and caliper size, while the CEM results are sensitive to the choice of matching characteristics. In some cases the results for industry specialist auditors reported in Table 4 are significantly weaker, but in others results remain robust. The absence of any discernible pattern in this extensive battery of PSM and CEM tests arguably lends support to the sentiments expressed by Lennox et al. (2012) regarding the limited ability of such techniques to adequately "control" for endogenous auditor choice.

As a final point, we highlight our use of a panel data design. Lennox et al. (2012) suggest that using a firm-specific fixed effect could eliminate the potential bias caused by endogeneity so long as the source of the endogeneity is constant over time. In a robustness test, we re-estimate equation (6) with firm fixed effects included (but year and industry fixed effects removed). We continue to find a positive and statistically significant association between measures of audit quality and changes in analysts' consensus and information precision. This result suggests that our results are robust to endogeneity concerns.

\subsection{SOX effects}

As a final way of addressing endogeneity concerns, we consider the adoption of the Sarbanes-Oxley Act (SOX) as an exogenous shock to audit quality and its impact on 
analysts' information environment. Passed in 2002, SOX created several restrictions on auditor-client relations such as banning the incumbent auditor from supplying many non-audit services to audit clients. It also created the Public Company Accounting Oversight Board (PCAOB), and an entirely new oversight and review process focusing on audit quality (Tanyi and Litt 2017). Proponents have argued that such regulation has the effect of improving audit quality via reduced threats to auditor independence, although research generally fails to find evidence in support of these claims (Ruddock et al. 2006). SOX increased the litigation risk associated with financial reporting and thus created a stronger demand for high quality audits. In response, consistent with an increase in audit quality, average audit reporting lags have increased significantly from 40 days in 2001, to 48 days in 2003 (Knechel and Sharma 2012). We thus expect that the adoption of SOX represents a positive shock to audit quality for U.S. firms. Since non-U.S. firms are not directly subject to SOX and thus not expected to experience a significant change in their audit quality, we use nonUS firms as a benchmark. A comparison between U.S. and non-U.S. firms sheds light on the effect of a positive shock to audit quality resulting from SOX adoption on the properties of analysts' information environment. We employ a difference-indifference research design to compare the changes in analysts' information environment around 2002 for the U.S. firms with the corresponding changes for nonU.S. firms. Specifically, we estimate the following regression model:

$$
\begin{gathered}
\mathrm{DV}=\alpha+\beta_{1} \mathrm{USA}+\beta_{2} \text { PostSOX }+\beta_{3} \mathrm{USA} \times \text { PostSOX }+\beta_{4} \text { Audit }+\beta_{5} \text { Surp }+\beta_{6} \text { Size }+ \\
\beta_{7} \mathrm{MB}+\beta_{8} \text { Analysts }+\varepsilon
\end{gathered}
$$

where DV are the changes in BKLS measures of analysts' information environment. USA is an indicator variable equal to 1 for the U.S. firms subject to SOX, and 0 for non-U.S. firms. PostSOX is an indicator variable for observations after 2002. We also include an interaction term between USA and PostSOX in the regressions, with control variables for the extent of the earnings surprise and firm characteristics as per the tests reported in Table 4 . The coefficient associated with $U S A\left(\beta_{1}\right)$ captures the difference in BKLS measures between U.S. and non-U.S. firms before 2002, while $\beta_{2}$ captures the changes in BKLS measures for non-U.S. firms after 2002 (i.e., PostSOX). The coefficient associated with the interaction term, USA $\times$ PostSOX, (i.e., $\beta_{3}$ ) captures the incremental changes in BKLS measures for U.S. firms, relative to the changes for 
non-U.S. firms. If the improvements in audit quality resulting from SOX adoption lead to improvements in analysts' information environment, we expect the coefficient of the interaction term to be positive.

We collect data on non-U.S. firms from Compustat Global and I/B/E/S and construct the BKLS measures of analysts' information environment. The sample selection procedure for non-U.S. firms is the same as that for the U.S. firms described in Section 3.2. We then combine the U.S. firms with the non-U.S. firms in the period from 1998 to 2007 to form the sample to estimate Equation 7. ${ }^{18}$

The results from the difference-in-differences design are reported in Table 5. The results show that $\beta_{1}$ is positive and statistically significant, suggesting that before 2002, U.S. firms demonstrate greater improvement in analysts' information environment around annual earnings announcements compared to non-U.S. firms. The coefficients on PostSOX $\left(\beta_{2}\right)$ are statistically indifferent from zero, suggesting that, for non-U.S. firms, the extent of any change in analysts' information environment around annual earnings releases for non-U.S. firms did not change after 2002. Most importantly, the interaction term $(U S A \times$ PostSOX) has a positive and statistically significant coefficient $\left(\beta_{3}\right)$ in all the models, suggesting that U.S. firms experienced a significantly larger improvement in analysts' information environment around earnings announcements after 2002, relative to non-U.S. firms. This evidence supports the view that SOX improved audit quality for U.S. firms, and thus was also associated with increased consensus among analysts around the release of annual earnings. This additional test using SOX adoption as an exogenous shock to audit quality therefore lends strong support to our main results in Table 4 that higher quality audits have a positive impact on analysts' information environment.

\section{Insert Table 5 here}

\section{Conclusions}

Inferences about the effect of audit quality on users of financial reports are typically

\footnotetext{
${ }^{18}$ This period includes five years before SOX adoption and five years after the adoption. We obtain similar results if we change the windows to 3 years or 10 years before and after the SOX adoption. Notice that this sample of U.S. and non-U.S. data, while including more countries, is a shorter timeperiod (1998-2007) than that for U.S. data employed in Table 4 (1985-2015); hence the smaller sample size in Table 5.
} 
based on tests using stock prices, experimental research using a limited number of actual subjects, or surveys. An alternative approach is suggested by Behn et al. (2008), who examine the association of audit quality with certain attributes of sell-side analysts' earnings forecasts. However, although they demonstrate increased accuracy and reduced dispersion when the auditor is a Big $\mathrm{N}$ audit firm, their results do not extend to the widely used notion of client-industry specialization as an indicator of audit quality. When viewed in conjunction with other research that fails to observe audit quality impacting on sell-side analysts (Donovan et al. 2014; Brown et al. 2015), the extent to which audit quality impacts capital market participants is uncertain. We therefore use a setting where the focus is on changes in analysts' information environment around the release of annual audited earnings. We expect that this window is most likely to capture the influence of audited financial data and, by extension, any incremental effect of expected differences in audit quality.

Our tests rely on widely-used measures of analysts' information environment (BKLS), whereby analysts' information set is characterized as comprising common and private information. If audit quality impacts the inputs to analysts' earnings forecasting process, we would expect common indicators of higher audit quality to be positively associated with changes in analysts' reliance on public information (i.e., including the audited financial statements), as well as a positive association with changes in the estimated precision of public information. Although audit quality may be positively associated with changes in the precision of private information, such effects would not be expected to outweigh the impact of audit quality on common information effects.

Using the BKLS method, we find that a Big N indicator and commonly used measures of auditor client-industry specialization are associated with a measure of increased consensus in revised forecasts issued shortly after earnings releases. This evidence indicates that analysts place increased weight on common sources of information relative to private information. This is precisely what we would expect if observable indicators of audit quality actually impact on the use of information applied in the forecasting process. Consistent with the consensus results, we also find a significantly higher increase in the precision of common information for clients audited by industry specialist auditors. While higher audit quality is also positively associated with increased precision in analysts' private information, this effect is not sufficient to 
outweigh the effects on common information.

Our use of a changes specification reduces to some extent concerns that endogenous auditor selection explains our results. Although cross-sectional differences in analysts' information environment may reflect factors which also underlie the demand for higher audit quality, our tests focus on changes in analysts' information environment over a short period, holding fixed the choice of audit quality. Our confidence in a causal interpretation is further enhanced by an additional test using the passage of SOX as an exogenous shock to audit quality, as well as the robustness of our results to the application of standard econometric procedures used to identify possible endogeneity effects. Our primary results are also robust to alternative indicators of differences in audit quality, such as audit fees and auditor tenure.

Overall, our evidence provides support for the argument that audit quality has capital market consequences, at least in so far as it impacts on sell-side analysts as users of accounting information. Our results also support the view that client industry specialization/leadership is an indicator of higher audit quality. Finally, our findings provide a more complete explanation for the findings in Behn et al. (2008), namely that analysts' earnings forecast accuracy is higher for firms audited by Big $\mathrm{N}$ auditors. Our analysis indicates that improved forecast accuracy may result from the fact that higher quality audits not only increase the precision of analysts' common information, but also assists analysts to develop more accurate private information. Of course, the precise channel by which audit quality impacts sell-side analysts is still to be specified. Whether that is via improved earnings predictability, lower variance, less conservatism or other specific attributes that might be associated with higher audit quality is an area for further research. 


\section{References}

Abarbanell, J., and B. Bushee. 1997. Fundamental analysis, future earnings, and stock prices. Journal of Accounting Research 35, 1 - 24.

Abernathy, J., T. Kang, G. Krishnan and C. Wang. 2016. Is there a relation between residual audit fees and analysts' forecasts? Journal of Accounting, Auditing and Finance (forthcoming).

Altschuler, D., G. Chen and J. Zhou. 2015. Anticipation of management forecasts and analysts private information search. Review of Accounting Studies 20, 803838.

Aobdia, D., C. Lin and R. Petacchi. 2015. Capital market consequences of audit partner quality. The Accounting Review 90, 2143-2176.

Audousset-Coulier, S., A. Jeny and L. Jiang. 2016. The validity of auditor industry specialization measures. Auditing: A Journal of Practice and Theory 35, 139161.

Autore, D., R. Billingsley and M. Schneller. 2009. Information uncertainty and auditor reputation. Journal of Banking and Finance 33, 183-192.

Ball, R., S. Jayaraman, and L. Shivakumar. 2012. Audited financial reporting and voluntary disclosure as complements: a test of the confirmation hypothesis. Journal of Accounting and Economics 53, 136 - 166.

Balsam, S., J. Krishnan, and J. Yang. 2003. Auditor industry specialization and earnings quality. Auditing: A Journal of Practice \& Theory 22, 71 - 97.

Barron, O., O. Kim, S. Lim, and D. Stevens. 1998. Using analysts' forecasts to measure properties of analysts' information environment. The Accounting Review 73, $421-433$.

Barron, O., D. Byard, C. Kile, and E. Riedl. 2002. High-technology intangibles and analysts' forecasts. Journal of Accounting Research 40, 289 - 312.

Barron, O., D. Byard, and O. Kim. 2002. Changes in analysts' information around earnings announcements. The Accounting Review 77, 821 - 846.

Barron, O., D. Byard, and Y. Yu. 2008. Earnings surprises that motivate analysts to reduce average forecast error. The Accounting Review 83, 303 - 325.

Barron, O., D. Byard, and Y. Yu. 2017. Earnings announcement disclosure and changes in analysts' information. Contemporary Accounting Research 34, $343-373$.

Barron, O., D. Harris, and M. Stanford. 2005. Evidence that investors trade on private event-period information around earnings announcements. The Accounting Review 80, 403 - 421.

Barron, O., M. Stanford, and Y. Yu. 2009. Further evidence on the relation between analysts' forecast dispersion and stock returns. Contemporary Accounting Research 26, 329 - 357.

Becker, C., M. DeFond, J. Jiambalvo, and K. Subramanyam. 1998. The effect of audit quality on earnings management. Contemporary Accounting Research 15, 1 24. 
Behn, B., J. Choi, and T. Kang. 2008. Audit quality and properties of analyst earnings forecasts. The Accounting Review 83, 327 - 349.

Beyer, A., D. Cohen, T. Lys, and B. Walther. 2010. The financial reporting environment: Review of the recent literature. Journal of Accounting and Economics 50, 296 - 343.

Blankley, A., D. N. Hurtt, and J. E. MacGregor. 2012. Abnormal audit fees and restatements. Auditing: A Journal of Practice \& Theory 31, 79-96.

Blankley, A., D. N. Hurtt, and J. E. MacGregor. 2014. The Relationship between Audit Report Lags and Future Restatements. Auditing: A Journal of Practice \& Theory 33, 27-57.

Botosan, C., M. Plumlee, and Y. Xie. 2004. The role of information precision in determining the cost of equity capital. Review of Accounting Studies 9, 233 259.

Bradshaw, M. 2009. Analyst information processing, financial regulation and academic research. The Accounting Review 84, 1073 - 1083.

Bradshaw, M., M. Plumlee, B. Whipple, and T. Yohn. 2018. The impact of earnings announcements on a firm's information environment. Working paper. Available at https://papers.ssrn.com/sol3/papers.cfm?abstract_id=2875839

Bradshaw, M, S. Richardson and R. Sloan. 2001. Do analysts and auditors use information in accruals? Journal of Accounting Research 39, 45 - 74.

Brown, L., A. Call, M. Clement, and N. Sharp. 2015. Inside the "black box" of sellside financial analysts. Journal of Accounting Research 53, 1- 47.

Byard, D. and K. Shaw. 2003. Corporate disclosure quality and properties of analysts' information environment. Journal of Accounting Auditing and Finance 18, $355-378$.

Byard, D., Y. Li and Y. Lu. 2011. The effect of mandatory IFRS adoption on financial analysts' information environment. Journal of Accounting Research 49, 6996.

Cahan, S., P. Chaney, D. Jeter and W. Zhang. 2013. Damaged auditor reputation and analysts' forecast revision frequency. Auditing: A Journal of Practice and Theory 32, 33 - 60.

Carey, P., and R. Simnett. 2006. Audit partner tenure and audit quality. The Accounting Review 81, 653-76.

Chen, Q., and W. Jiang. 2006. Analysts' weighting of private and public information. Review of Financial Studies 19, 319 - 355.

Craswell, A., J. Francis, and S. Taylor. 1995. Auditor brand name reputations and industry specializations. Journal of Accounting and Economics 20, 297 - 322.

Dechow, P., S. Richardson and I. Tuna. 2003. Why are earnings kinky? An examination of the earnings management explanation, Review of Accounting Studies 8, 355 - 384 .

Dechow, P., W. Ge, and C. Schrand. 2010. Understanding earnings quality: A review of the proxies, their determinants and their consequences. Journal of Accounting and Economics 50, 344 - 401. 
DeBoskey, D., and W. Jiang. 2012. Earnings management and auditor industry specialization in the post-SOX era: An examination of the banking industry. Journal of Banking and Finance 36, 613-623.

DeFond, M., C. Lim and Y. Zhang. 2014. Client conservatism and auditor client contracting. Working paper. University of Southern California and Singapore Management University.

DeFond, M., and J. Zhang. 2014. A review of archival auditing research. Journal of Accounting and Economics 58, 275 - 326.

DeFond, M., D. H. Erkens, and J. Zhang. 2017. Do client characteristics really drive the Big $\mathrm{N}$ audit quality effect? New evidence from propensity score matching. Management Science 63, 3628-3649.

Donovan, J., R. Frankel, J. Lee, X. Martin and H. Seo. 2014. Issues raised by studying DeFond and Zhang: What should audit researchers do? Journal of Accounting and Economics 58: 327-338.

Durtschi, C. and P. Easton. 2005. Earnings management? The shape of the frequency distribution of earnings metrics are not evidence ipso facto. Journal of Accounting Research 43, 557 - 592.

Durtschi, C. and P. Easton. 2009. Earnings management? Erroneous inferences based on earnings frequency distributions. Journal of Accounting Research 47, $1249-1282$.

Fama, E., and J. MacBeth. 1973. Risk, return and equilibrium: Empirical tests. The Journal of Political Economy 81, 607 - 637.

Feltham, G., J. Hughes and D. Simunic. 1991. Empirical assessment of the impact of auditor quality on the valuation of new issues. Journal of Accounting and Economics 14, 375 - 399.

Francis, J. 2011. A framework for understanding and researching audit quality. Auditing: A Journal of Practice and Theory 30, 125-152.

Francis, J., K. Reichelt and D. Wang. 2005. The pricing of national and city-specific reputations for industry expertise in the US audit market. The Accounting Review 80, 113 - 136.

Geiger, M. A., and K. Raghunandan. 2002. Auditor tenure and audit reporting failures. Auditing: A Journal of Practice and Theory 21, 67-78.

Gow, I., G. Ormazabal and D. Taylor. 2010. Correcting for cross-sectional and timeseries dependence in accounting research. The Accounting Review 85, 483 512.

Gu, Z. 2004. Measuring the precision of analysts' private and common information: Generalization and an application. Working paper, Carnegie Mellon University.

Hahn, T. and M. Song. 2013. Regulation Fair Disclosure and analysts' reliance on earnings announcements. Journal of Accounting and Public Policy 32, 26 43.

Han, S., J.Y. Jin, T. Kang and G. Lobo. 2013. Managerial ownership and financial analysts' information environment. Journal of Business Finance and Accounting 41, 328 - 362. 
Heckman, J. 1979. The sample selection bias as a specification error. Econometrica $47,153-162$.

Holthausen, R., and R. Verrecchia. 1990. The effect of informedness and consensus on price and volume behaviour. The Accounting Review 65, 191 - 208.

Jin, Y.J., K. Kanagaretnam and G. Lobo. 2011. Ability of accounting and audit quality variables to predict bank failure during the financial crisis. Journal of Banking and Finance 35, 2811-2819.

Kanagaretnam, K., C.Y. Lim and G. Lobo. 2010. Auditor reputation and earnings management: International evidence from the banking industry.

Keshk, W. and J. Wang. 2018. Determinants of the relationship between investor sentiment and analysts' private information production. Journal of Business Finance and Accounting (forthcoming), doi:10.1111/jbfa.12340.

Kim, O. and R. Verrecchia. 1991. Trading volume and price reactions to public announcements. Journal of Accounting Research 29, 302 - 321.

Kim, O. and R. Verrecchia. 1994. Market liquidity and volume around earnings announcements. Journal of Accounting and Economics 17, $41-67$.

Kim, O. and R. Verrecchia. 1997. Pre-announcement and event period private information. Journal of Accounting and Economics 24, 395 - 419.

Knechel, W. R., and D. S. Sharma. 2012. "Auditor-provided nonaudit services and audit effectiveness and efficiency: Evidence from pre- and post-SOX audit report lags", Auditing, A Journal of Practice and Theory 31, 85-114.

Krishnan, G. 2003. Audit quality and the pricing of discretionary accruals. Auditing: A Journal of Practice \& Theory 22, $109-126$.

Lawrence, A., M. Minutti-Meza and P. Zhang. 2011. Can Big 4 versus non-Big 4 differences in audit-quality proxies be attributed to client characteristics? The Accounting Review 86, 259 - 286.

Lennox, C., J. Francis and Z. Wang. 2012. Selection models in accounting research. The Accounting Review 87, 589 - 616.

Lys, T., and L. Soo. 1995. Analysts' forecast precision as a response to competition. Journal of Accounting, Auditing and Finance 10, 751 - 765.

Mansi, S., W. Maxwell and D. Miller. 2004. Does auditor quality and tenure matter to investors? Evidence from the bond market. Journal of Accounting Research $42,755-793$.

Minutti-Meza, M. 2013. Does auditor industry specialization improve audit quality? Journal of Accounting Research 51, 779 - 817.

Mohanram, P., and S. Sunder. 2006. How has Regulation FD affected the operations of financial analysts? Contemporary Accounting Research 23, 491 - 525.

Payne, J. 2008. The influence of audit firm specialization on analyst forecast errors, Auditing: A Journal of Practice and Theory 27, 109 - 136.

Payne, J. and W. Thomas. 2003. The implications of using stock-split adjusted I/B/E/S in empirical research. The Accounting Review 78, 1049 - 1068.

Petersen, M. 2009. Estimating standard errors in finance panel data sets: Comparing approaches. Review of Financial Studies 22, 435 - 480. 
Pittman , J. and S. Fortin. 2004. Auditor choice and the cost of debt capital for newly public firms, Journal of Accounting and Economics 37, 113 - 136.

Reichelt, K., and D. Wang. 2010. National and office-specific measures of auditor industry expertise and effects on audit quality. Journal of Accounting Research 48, 647 - 686.

Ruddock, C., S.J. Taylor and S.L. Taylor. 2006. Non-audit services and earnings conservatism: Is auditor independence impaired? Contemporary Accounting Research 23, $701-746$.

Schipper, K. 1991. Analysts' forecasts. Accounting Horizons 5, $105-121$.

Tanyi, P. and B. Litt. 2017. The unintended consequences of the frequency of PCAOB inspection. Journal of Business Finance and Accounting 44, 116153.

Teoh, S., and T. Wong. 1993. Perceived auditor quality and the earnings response coefficient. The Accounting Review 68, 346 - 366.

Verrecchia, R. 1982. The use of mathematical models in financial accounting. Journal of Accounting Research 20 (Supp.), 1 - 42.

Watts, R., and J. Zimmerman. 1981. Auditors and the determination of accounting standards. Working paper, University of Rochester, Rochester, NY.

Weber, J. and M. Willenborg. 2003. Do expert informational intermediaries add value? Evidence from auditors in microcap initial public offerings. Journal of Accounting Research 41, 681 - 720.

Wu A. and M. Wilson. 2016. Audit quality and analyst forecast accuracy: The impact of forecast horizon and other modeling choices. Auditing: A Journal of Practice and Theory 35, 167-185.

Xie, H., 2001. The mispricing of abnormal accruals. The Accounting Review 76, 357 374.

Yezegel, A. 2015. Why do analysts revise their stock recommendations after earnings announcements? Journal of Accounting and Economics 59, 163-181.

Zhang, Y. 2008. Analyst responsiveness and the post-earnings-announcement drift. Journal of Accounting and Economics 46, 201 - 215. 


\section{Appendix \\ Variable Definitions}

\begin{tabular}{|c|c|}
\hline Variable & Definition \\
\hline \multicolumn{2}{|c|}{ Dependent Variables } \\
\hline$\Delta \rho$ & $\begin{array}{l}\text { Changes in BKLS measure of consensus among financial analysts (estimated from } \\
\text { Equation 1) from before to after the annual earnings announcement. }\end{array}$ \\
\hline$\Delta h$ & $\begin{array}{l}\text { Changes in BKLS measure of the precision of analysts' common information } \\
\text { (estimated from Equation 2) from before to after the annual earnings announcement. }\end{array}$ \\
\hline$\Delta s$ & $\begin{array}{l}\text { Changes in BKLS measure of the precision of analysts' private information } \\
\text { (estimated from Equation 3) from before to after the annual earnings announcement. }\end{array}$ \\
\hline \multicolumn{2}{|c|}{ Measures of audit quality } \\
\hline BigN & $\begin{array}{l}\text { An indicator variable equal to } 1 \text { if the firm's audit is one of the Big } \mathrm{N} \text { audit firms, } \\
\text { and } 0 \text { otherwise. }\end{array}$ \\
\hline Share & $\begin{array}{l}\text { Market share (measured in client sales) of the firm's auditor in an industry defined } \\
\text { by two-digit SIC codes. }\end{array}$ \\
\hline Leader & $\begin{array}{l}\text { An indicator variable equal to } 1 \text { if the firm's auditor has largest market share } \\
\text { (measured in client sales) in an industry defined by two-digit SIC codes, and } 0 \\
\text { otherwise. }\end{array}$ \\
\hline Sharecl & $\begin{array}{l}\text { Market share (measured in number of clients) of the firm's auditor in an industry } \\
\text { defined by two-digit SIC codes. }\end{array}$ \\
\hline Mostcl & $\begin{array}{l}\text { An indicator variable equal to } 1 \text { if the firm's auditor has largest market share } \\
\text { (measured in number of clients) in an industry defined by two-digit SIC codes, and } 0 \\
\text { otherwise. }\end{array}$ \\
\hline \multicolumn{2}{|c|}{ Other variables } \\
\hline Analysts & Number of individual analysts' forecasts used in estimating $\rho, \mathrm{h}$ and s. \\
\hline MB & Market-to-Book ratio. \\
\hline PostSOX & An indicator variable equal to 1 for observations after 2002 , and 0 otherwise \\
\hline Size & Natural logarithm of the firm's market capitalization. \\
\hline Surp & $\begin{array}{l}\text { Earnings surprise, calculated as the absolute value of the difference between actual } \\
\text { earnings per share and mean analyst forecasts made } 60 \text { days before the earnings } \\
\text { announcements, scaled by the absolute value of actual earnings per share. }\end{array}$ \\
\hline USA & An indicator variable equal to 1 for U.S. firms, and 0 for firms in non-U.S. markets \\
\hline
\end{tabular}


Table 1

Sample Selection

This table outlines the sample selection procedure. The sample period covers 1985 to 2015 .

\begin{tabular}{lcc}
\hline & $\begin{array}{c}\text { Firm-Year } \\
\text { Observations }\end{array}$ & $\begin{array}{c}\text { Unique } \\
\text { Firms }\end{array}$ \\
\hline Firms with at least two analysts issuing forecasts for year $\mathrm{t}+1$ & & \\
earnings within 60 days before announcement of year t earnings & 56,621 & 9,701 \\
Firms with at least two analysts revising forecasts for year $\mathrm{t}+1$ & & \\
earning within 30 days after announcement of year t earnings & 34,854 & 7,053 \\
Firms with precision of analysts' information & 32,455 & 6,793 \\
Firms with positive value for the precision of analysts' information & 28,416 & 6,468 \\
Firms with non-missing accounting data from Compustat & 25,111 & 5,353 \\
\hline
\end{tabular}


Table 2

Descriptive Statistics

This table presents descriptive statistics for a sample of 25,111 firm-year observations over the period from 1985 to 2015. Variables are defined in the Appendix.

\begin{tabular}{lccccc}
\hline Variable & Mean & Std Dev & Q1 & Median & Q3 \\
\hline$\Delta \rho$ & 0.076 & 0.350 & -0.042 & 0.003 & 0.110 \\
$\Delta h$ & 66.065 & 278.435 & 0.002 & 1.371 & 19.735 \\
$\Delta s$ & -14.712 & 258.188 & -0.749 & 0.002 & 1.367 \\
BigN & 0.943 & 0.232 & 1.000 & 1.000 & 1.000 \\
Share & 0.240 & 0.142 & 0.136 & 0.227 & 0.320 \\
Leader & 0.290 & 0.454 & 0.000 & 0.000 & 1.000 \\
Sharecl & 0.181 & 0.076 & 0.133 & 0.174 & 0.221 \\
Mostcl & 0.233 & 0.423 & 0.000 & 0.000 & 0.000 \\
Surp & 0.159 & 0.419 & 0.011 & 0.034 & 0.103 \\
Size & 7.746 & 1.673 & 6.564 & 7.671 & 8.879 \\
MB & 3.209 & 4.240 & 1.416 & 2.262 & 3.781 \\
Analysts & 5.048 & 4.124 & 2.000 & 4.000 & 6.000 \\
\hline
\end{tabular}


Table 3

\section{Correlation Coefficients of Ranked Variables}

This table reports correlation coefficients for the variables. Variables are as defined in the Appendix and transformed into their rankings each year within an industry defined by two-digit SIC codes. All the coefficients are statistically significant at $1 \%$ level.

\begin{tabular}{|c|c|c|c|c|c|c|c|c|c|c|c|}
\hline & $\Delta \rho$ & $\Delta h$ & $\Delta s$ & BigN & Share & Leader & Sharecl & Mostcl & Surp & Size & MB \\
\hline$\Delta h$ & 0.664 & & & & & & & & & & \\
\hline$\Delta s$ & 0.350 & 0.628 & & & & & & & & & \\
\hline BigN & 0.703 & 0.708 & 0.701 & & & & & & & & \\
\hline Share & 0.611 & 0.616 & 0.610 & 0.868 & & & & & & & \\
\hline Leader & 0.723 & 0.726 & 0.723 & 0.871 & 0.866 & & & & & & \\
\hline Sharecl & 0.612 & 0.614 & 0.610 & 0.820 & 0.817 & 0.805 & & & & & \\
\hline Mostcl & 0.732 & 0.731 & 0.729 & 0.862 & 0.785 & 0.917 & 0.850 & & & & \\
\hline Surp & 0.595 & 0.581 & 0.621 & 0.701 & 0.601 & 0.724 & 0.611 & 0.736 & & & \\
\hline Size & 0.602 & 0.620 & 0.589 & 0.769 & 0.702 & 0.746 & 0.645 & 0.729 & 0.524 & & \\
\hline $\mathrm{MB}$ & 0.595 & 0.620 & 0.590 & 0.703 & 0.616 & 0.727 & 0.618 & 0.733 & 0.548 & 0.712 & \\
\hline Analysts & 0.625 & 0.658 & 0.659 & 0.780 & 0.693 & 0.784 & 0.671 & 0.780 & 0.611 & 0.774 & 0.665 \\
\hline
\end{tabular}


Table 4

Regression Analysis of Changes in Analysts' Information Environment

This table presents the summary regression results from the following model:

$$
\Delta \rho(\Delta h, \Delta s)=\alpha_{0}+\alpha_{1} \text { Audit Quality }+\alpha_{2} \text { Surp }+\alpha_{3} \text { Size }+\alpha_{4} \mathrm{MB}+\alpha_{5} \text { Analyst }+\varepsilon
$$

where Audit Quality is measured by Share, Leader, Sharecl, Mostcl, respectively. The sample consists of 25,111 firm-year observations over the period from 1985 to 2015. Variables are defined in the Appendix, and transformed into their rankings each year within an industry defined by two-digit SIC codes. Standard errors are adjusted for both firm and year clusters. T-statistics are reported beneath the coefficients. ***, **, and * indicate that the coefficients are significant at $1 \%, 5 \%$ and $10 \%$ level.

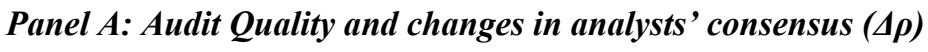

\begin{tabular}{|c|c|c|c|c|c|}
\hline Variable & $\begin{array}{c}\text { BigN } \\
(1)\end{array}$ & $\begin{array}{c}\text { Share } \\
(2)\end{array}$ & $\begin{array}{c}\text { Leader } \\
\text { (3) }\end{array}$ & $\begin{array}{c}\text { Sharecl } \\
(4)\end{array}$ & $\begin{array}{c}\text { Mostcl } \\
(5)\end{array}$ \\
\hline Audit & $\begin{array}{c}0.537 * * * \\
(16.35)\end{array}$ & $\begin{array}{c}0.163 * * * \\
(17.74)\end{array}$ & $\begin{array}{c}0.263 * * * \\
(25.00)\end{array}$ & $\begin{array}{c}0.211 * * * \\
(15.49)\end{array}$ & $\begin{array}{c}0.466^{* * *} \\
(14.96)\end{array}$ \\
\hline Surp & $\begin{array}{c}0.149 * * * \\
(8.89)\end{array}$ & $\begin{array}{c}0.253 * * * \\
(24.50)\end{array}$ & $\begin{array}{c}0.220 * * * \\
(24.69)\end{array}$ & $\begin{array}{c}0.233 * * * \\
(20.59)\end{array}$ & $\begin{array}{c}0.147 * * * \\
(12.25)\end{array}$ \\
\hline Size & $\begin{array}{c}0.050 * * * \\
(3.69)\end{array}$ & $\begin{array}{c}0.153 * * * \\
(10.14)\end{array}$ & $\begin{array}{c}0.149 * * * \\
(10.15)\end{array}$ & $\begin{array}{c}0.178 * * * \\
(12.10)\end{array}$ & $\begin{array}{c}0.155^{* * *} * \\
(11.03)\end{array}$ \\
\hline MB & $\begin{array}{c}0.122 * * * \\
\quad(9.07)\end{array}$ & $\begin{array}{c}0.172 * * * \\
(13.24)\end{array}$ & $\begin{array}{c}0.145^{* * *} * \\
(10.91)\end{array}$ & $\begin{array}{c}0.144 * * * \\
(10.24)\end{array}$ & $\begin{array}{c}0.090 * * * \\
(6.36)\end{array}$ \\
\hline Analysts & $\begin{array}{c}0.039 * * * \\
(2.97)\end{array}$ & $\begin{array}{c}0.099 * * * \\
\quad(9.09)\end{array}$ & $\begin{array}{c}0.081 * * * \\
(7.67)\end{array}$ & $\begin{array}{c}0.087 * * * \\
(8.14)\end{array}$ & $\begin{array}{c}0.042 * * * \\
(3.51)\end{array}$ \\
\hline Intercept & $\begin{array}{c}2.378 * * * \\
(7.65)\end{array}$ & $\begin{array}{c}3.711 * * * \\
(9.72)\end{array}$ & $\begin{array}{c}3.287 * * * \\
(9.52)\end{array}$ & $\begin{array}{c}3.409 * * * \\
(10.23)\end{array}$ & $\begin{array}{c}2.313 * * * \\
(10.91)\end{array}$ \\
\hline $\mathrm{N}$ & 25,111 & 25,111 & 25,111 & 25,111 & 25,111 \\
\hline $\mathrm{R}^{2}$ & 0.494 & 0.457 & 0.468 & 0.468 & 0.497 \\
\hline
\end{tabular}


Panel B: Audit Quality and changes in analysts' common information (4h)

\begin{tabular}{lccccc}
\hline Variable & BigN & Share & Leader & Sharecl & Mostcl \\
& $(1)$ & $(2)$ & $(3)$ & $(4)$ & $(5)$ \\
\hline Audit & $0.523 * * *$ & $0.169 * * *$ & $0.266^{* * *}$ & $0.193 * * *$ & $0.433 * * *$ \\
& $(16.40)$ & $(12.40)$ & $(18.03)$ & $(20.91)$ & $(14.91)$ \\
Surp & $0.052 * * *$ & $0.151^{* * *}$ & $0.119 * * *$ & $0.138^{* * *}$ & $0.057 * * *$ \\
& $(3.11)$ & $(11.30)$ & $(9.55)$ & $(10.27)$ & $(3.70)$ \\
Size & $0.098^{* * *}$ & $0.195 * * *$ & $0.192^{* * *}$ & $0.224 * * *$ & $0.203 * * *$ \\
& $(5.91)$ & $(11.97)$ & $(12.29)$ & $(14.11)$ & $(13.02)$ \\
MB & $0.163 * * *$ & $0.211^{* * *}$ & $0.184 * * *$ & $0.187 * * *$ & $0.137 * * *$ \\
& $(13.61)$ & $(16.35)$ & $(14.05)$ & $(14.57)$ & $(10.33)$ \\
Analysts & $0.066 * * *$ & $0.123 * * *$ & $0.105 * * *$ & $0.115 * * *$ & $0.072 * * *$ \\
& $(4.33)$ & $(9.33)$ & $(8.63)$ & $(9.76)$ & $(5.93)$ \\
Intercept & $2.253 * * *$ & $3.514 * * *$ & $3.101 * * *$ & $3.301 * * *$ & $2.271 * * *$ \\
& $(7.45)$ & $(9.48)$ & $(9.24)$ & $(9.81)$ & $(10.42)$ \\
$\mathrm{N}$ & & & & & 25,111 \\
$\mathrm{R}^{2}$ & 25,111 & 25,111 & 25,111 & $0.48)$ & 0.509 \\
\hline
\end{tabular}

Panel C: Audit Quality and changes in analysts' private information (4s)

\begin{tabular}{|c|c|c|c|c|c|}
\hline Variable & $\begin{array}{c}\mathrm{BigN} \\
(1) \\
\end{array}$ & $\begin{array}{c}\text { Share } \\
(2) \\
\end{array}$ & $\begin{array}{c}\text { Leader } \\
(3) \\
\end{array}$ & $\begin{array}{c}\text { Sharecl } \\
(4) \\
\end{array}$ & $\begin{array}{c}\text { Mostcl } \\
(5)\end{array}$ \\
\hline Audit & $\begin{array}{c}0.447 * * * \\
(15.69)\end{array}$ & $\begin{array}{c}0.147 * * * \\
(13.47)\end{array}$ & $\begin{array}{c}0.224 * * * \\
(17.42)\end{array}$ & $\begin{array}{c}0.156 * * * \\
(14.17)\end{array}$ & $\begin{array}{c}0.369 * * * \\
(10.74)\end{array}$ \\
\hline Surp & $\begin{array}{c}0.168 * * * \\
(17.75)\end{array}$ & $\begin{array}{c}0.252 * * * \\
(38.76)\end{array}$ & $\begin{array}{c}0.226^{* * *} * \\
(34.08)\end{array}$ & $\begin{array}{c}0.244 * * * \\
(44.00)\end{array}$ & $\begin{array}{c}0.173 * * * \\
(13.78)\end{array}$ \\
\hline Size & $\begin{array}{l}0.003 \\
(0.20)\end{array}$ & $\begin{array}{c}0.085^{* * *} * \\
(5.14)\end{array}$ & $\begin{array}{c}0.084 * * * \\
(5.31)\end{array}$ & $\begin{array}{c}0.113 * * * \\
(7.80)\end{array}$ & $\begin{array}{c}0.093 * * * \\
(6.70)\end{array}$ \\
\hline MB & $\begin{array}{c}0.124 * * * \\
(15.06)\end{array}$ & $\begin{array}{c}0.164 * * * \\
(23.70)\end{array}$ & $\begin{array}{c}0.142 * * * \\
(20.96)\end{array}$ & $\begin{array}{c}0.147 * * * \\
(18.89)\end{array}$ & $\begin{array}{c}0.102 * * * \\
(9.93)\end{array}$ \\
\hline Analysts & $\begin{array}{c}0.167 * * * \\
(11.95)\end{array}$ & $\begin{array}{c}0.215^{* * *} * \\
(16.39)\end{array}$ & $\begin{array}{c}0.201 * * * \\
(15.26)\end{array}$ & $\begin{array}{c}0.211 * * * \\
(14.53)\end{array}$ & $\begin{array}{c}0.173 * * * \\
(10.83)\end{array}$ \\
\hline Intercept & $\begin{array}{c}2.079 * * * \\
(7.69)\end{array}$ & $\begin{array}{c}3.152 * * * \\
(9.33)\end{array}$ & $\begin{array}{c}2.817 * * * \\
(9.11)\end{array}$ & $\begin{array}{c}3.014 * * * \\
(9.80)\end{array}$ & $\begin{array}{c}2.104 * * * \\
(11.12)\end{array}$ \\
\hline $\mathrm{N}$ & 25,111 & 25,111 & 25,111 & 25,111 & 25,111 \\
\hline $\mathrm{R}^{2}$ & 0.509 & 0.485 & 0.492 & 0.487 & 0.508 \\
\hline
\end{tabular}




\section{Table 5}

\section{Effect of SOX on Analysts' Information Properties}

This table reports regression results from the following model:

$\Delta \rho(\Delta \mathrm{h}, \Delta \mathrm{s})=\alpha_{0}+\alpha_{1}$ USA $+\alpha_{2}$ PostSOX $+\alpha_{3}$ USA $\times$ PostSOX $+\alpha_{4}$ Surp $+\alpha_{5}$ Size $+\alpha_{6}$ MB $+\alpha_{7}$ Analysts $+\varepsilon$ using a sample for firm-year observations from U.S. and non-U.S. markets during the period from 1998 to 2007. Variables are defined in the Appendix. Except USA and PostSOX, variables are transformed into their rankings each year within an industry defined by two-digit SIC codes. Standard errors are adjusted for both firm and year clusters. T-statistics are reported beneath the coefficients. ***, **, and * indicate that the coefficients are significant at $1 \%, 5 \%$ and $10 \%$ level.

\begin{tabular}{lccc}
\hline Variable & $\Delta \rho$ & $\Delta h$ & $\Delta s$ \\
& $(4)$ & $(5)$ & $(6)$ \\
\hline USA & $8.197^{* * *}$ & $11.450^{* * *}$ & $8.884^{* * *}$ \\
& $(4.61)$ & $(4.84)$ & $(6.89)$ \\
PostSOX & -0.916 & -0.359 & 0.062 \\
& $(-0.79)$ & $(-0.28)$ & $(0.12)$ \\
USA $\times$ PostSOX & $4.875^{* *}$ & $4.440^{* *}$ & $3.652^{* *}$ \\
& $(2.14)$ & $(2.21)$ & $(2.07)$ \\
Surp & $0.211^{* * *}$ & $0.184^{* * *}$ & $0.234^{* * *}$ \\
& $(14.70)$ & $(10.65)$ & $(19.54)$ \\
Size & $0.197^{* * *}$ & $0.139^{* * *}$ & $0.113^{* * *}$ \\
& $(15.80)$ & $(7.51)$ & $(7.78)$ \\
MB & $0.205^{* * *}$ & $0.206^{* * *}$ & $0.219 * * *$ \\
& $(13.81)$ & $(13.30)$ & $(21.16)$ \\
Analysts & $0.178^{* * *}$ & $0.240^{* * *}$ & $0.224 * * *$ \\
& $(13.62)$ & $(20.43)$ & $(11.14)$ \\
Constant & -0.802 & $-2.557^{* * *}$ & $-1.270^{* * *}$ \\
& $(-1.12)$ & $(-2.86)$ & $(-3.25)$ \\
& & & \\
$\mathrm{N}$ & 13,546 & 13,546 & 13,546 \\
$\mathrm{R}^{2}$ & 0.452 & 0.440 & 0.450 \\
\hline
\end{tabular}

